\title{
Comparison of the Khom Script Manuscripts of the Majjhimanikāya Found in Thailand and Cambodia
}

\author{
Suchada SRISETTHAWORAKUL
}

\section{Background and Previous Research}

According to the study of history of Buddhism in Southeast Asia, specifically in Siamese kingdom and later Khmer kingdom in the previous research "A Problem on the Origin of the Pāli Canon of Khom Script Manuscripts Found in Thailand and Cambodia”, ${ }^{1)}$ the evidence of transmission of Theravada Buddhism and manuscripts of the Pāli Canon in Khmer Kingdom is scarce and what evidence there is indirect. On the other hand, Siamese and related chronicles show a lot of concrete evidences of the transmission of Theravada Buddhism and manuscripts of the Pāli Canon in the area of the Siamese kingdom. Moreover, most Khom script manuscripts have no colophon which creates difficulty in knowing about their origin and age with any certainty. The data, that appears in the chronicles or historical documents, seems to support the theory that the Khom script manuscripts of the Pāli canon in Cambodia are influenced by those from Thailand. However, the evidence is insufficient to determine the origin in both countries. Therefore, to clarify this issue, a preliminary comparative study of selected texts of the Pāli canon in Khom script manuscripts is necessary. In this paper, a portion of the Mūlapaṇnāsa of the Majjhimanikāya will be used for a comparative study of the Khom script manuscripts found in both countries.

\section{Overview of Selected Khom Script Manuscripts}

\subsection{Selected Khom script manuscripts of the Pāli canon from Thailand (K01-K05)}

Five sets of Khom script manuscript of the Pāli Canon from Thailand are selected as research materials. The first manuscript (K01) is found at Wat Phrananchoeng, Ayutthaya. It was created in 1779 CE or Thonburi Period (King Taksin). The second manuscript (K02) is from 
National Library, Bangkok, the year of creation is unknown. The next one (K03) is found at Wat Phra Chetupon (Wat Pho), Bangkok. Its edition is Thep Chum Num, the special edition of King Rama III, therefore, its creation time can be dated around 1824-1854. The last two manuscripts (K04 and K05) are from National Library, Bangkok and were created during the Rattanakosin Period (King Rama III). The detail of each manuscript shows as follow.

\subsection{Selected Khom script manuscripts of the Pāli canon from Cambodia (K95)}

In 2015, the DTP digitized Khom script manuscript of the Pāli Canon from Vat Saravan Techo, Phnom Penh, Cambodia (K95). The period of creating this manuscript is unknown and only one phuk, the phuk number 6, had been found. Its content is Sīhanādavagga of the Mūlapaṇn̄āsa in the Majjhimanikāya, beginning from the end of the Mahāsīhanādasutta to the end of the Anumānasutta. The first page of the manuscript shows the text title and the table of contents. The table of contents shows the sutta titles along with alphabetical page numbers, but they are written in Thai language with Khom script.

\section{Comparison of Selected Khom Script Manuscripts}

When comparing the above Khom script manuscripts, it is useful to include palm-leaf manuscripts from other traditions as well in order to gain a larger view of the manuscript transmission in the Theravada tradition. The process of comparison starts by transliterating the content of each selected manuscript from local scripts such as Khom, Tham, Mon, Burmese, and Sinhalese into the roman script. The transcriptions have been used for

\begin{tabular}{|l|c|c|l|l|}
\hline \multicolumn{1}{|c|}{$\begin{array}{c}\text { Manuscript } \\
\text { Code }\end{array}$} & $\begin{array}{l}\text { Inscribed } \\
\text { year }(\mathrm{CE})\end{array}$ & $\begin{array}{c}\text { Age } \\
\text { (years) }\end{array}$ & \multicolumn{1}{c|}{ Reign } & \multicolumn{1}{c|}{ Location } \\
\hline $\begin{array}{l}\text { K01: } \\
\text { TH_08_01_004_00_01 }\end{array}$ & 1779 & 239 & $\begin{array}{l}\text { King Taksin } \\
\text { (Thonburi Period) }\end{array}$ & $\begin{array}{l}\text { Wat Phrananchoeng, } \\
\text { Ayutthaya, Thailand }\end{array}$ \\
\hline $\begin{array}{l}\text { K02: } \\
\text { TH_05_01_036_00_01 }\end{array}$ & Unknown & Unknown & Unknown & $\begin{array}{l}\text { National Library, } \\
\text { Bangkok, Thailand }\end{array}$ \\
\hline $\begin{array}{l}\text { K03: } \\
\text { TH_04_01_999_00_01 }\end{array}$ & $1824-1854$ & $164-194$ & $\begin{array}{l}\text { Unknown } \\
\text { Thep Chum Num Ed. } \\
\text { (King Rama III) }\end{array}$ & $\begin{array}{l}\text { Wat Phra Chetupon } \\
\text { (Wat Pho), Bangkok, } \\
\text { Thailand }\end{array}$ \\
\hline $\begin{array}{l}\text { K04: } \\
\text { TH_05_01_035_00_01 }\end{array}$ & 1841 & 177 & $\begin{array}{l}\text { King Rama III } \\
\text { (Rattanokosin Period) }\end{array}$ & $\begin{array}{l}\text { National Library, } \\
\text { Bangkok, Thailand }\end{array}$ \\
\hline $\begin{array}{l}\text { K05: } \\
\text { TH_05_01_034_00_01 }\end{array}$ & 1848 & 170 & $\begin{array}{l}\text { King Rama III } \\
\text { (Rattanokosin Period) }\end{array}$ & $\begin{array}{l}\text { National Library, } \\
\text { Bangkok, Thailand }\end{array}$ \\
\hline
\end{tabular}

Figure 1 A detail of five sets of selected Khom script manuscripts of the Pāli Canon from Thailand 


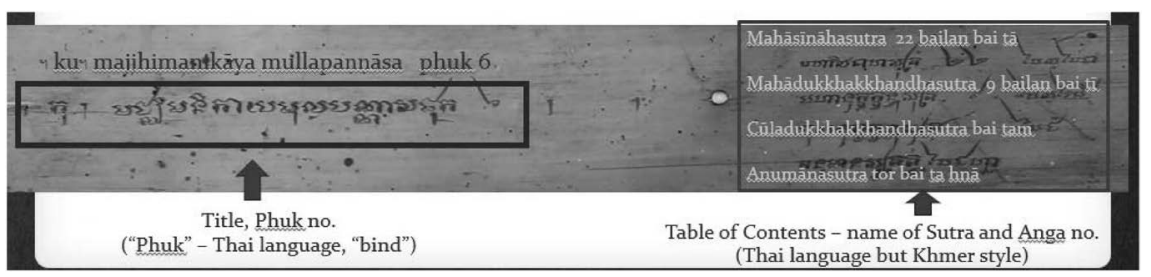

Figure 2 The first page of selected Khom script manuscript of the Pāli Canon from Cambodia

\section{Comparison of Selected Khom Script Manuscripts}

\begin{tabular}{|c|c|c|c|c|c|c|}
\hline \multirow{8}{*}{$\begin{array}{l}\text { - Burmese printed edition } \\
\text { (Chațtha sañgãyana Tipițaka) }\end{array}$} & \multicolumn{6}{|c|}{ Synoptic table of the content } \\
\hline & $\begin{array}{r}\text { MHO1 } \\
\text { Bo1 }\end{array}$ & $\begin{array}{l}\text { apariyadinnàyevassa } \\
\text { apariyudilinnayevasava }\end{array}$ & $\begin{array}{l}\text { säriputta } \\
\text { sáriputta }\end{array}$ & $\begin{array}{l}\text { tathaigatassa } \\
\text { tathagatassa }\end{array}$ & $\begin{array}{l}\text { dhammadesana } \\
\text { dhammadesana }\end{array}$ & $\begin{array}{l}\text { apariyadilinnamyevassa } \\
\text { aparlyddinnamyevassa }\end{array}$ \\
\hline & 802 & aparlyadinnayevasava & sariputta & tathagatassa & dhammadesana & apariyadinnamyevassa \\
\hline & 803 & apariyłdinnłyevassa & sâriputta & tathagatassa & dhammadesana & apariyaddinnamyevassa \\
\hline & 804 & apariyädinnāyevassa & săriputta & tathâgatassa & dhammadesana & apariyādinnamyevassa \\
\hline & Bos & apariyadinnđyyevassa & săriputta & tathagatassa & dhammadesana & apariyadinnamyevassa \\
\hline & Be & apariyadinnayevassa & sâriputta & tathagatassa & dhammadesana & apariyaddinnamyevassa \\
\hline & $\mathrm{col}$ & apariyådinnałyevassa & sâriputta & tathagatassa & dhammadesand & apariyadinnayevassa \\
\hline \multirow{9}{*}{$\begin{array}{l}\text { - Transliteration from } \\
\text { "Local script" to "Roman script" }\end{array}$} & $\mathrm{CO} 2$ & apariyädinnâyevassa & sâriputta & tathâgatassa & dhammadesană & apariyâdipnamyevassa \\
\hline & $\mathrm{CO}$ & apariyvadinnayevassa & sâriputta & tathăgatassa & dhammadesanam & aparlyădinnamyevassa \\
\hline & $\mathrm{cos}$ & apariyadinnnäyevassa & sâriputta & tathăgatassa & dhammadesana & apariyädinnamyevassa \\
\hline & $\cos$ & aparlyädinnāyevassa & sâriputta & tathăgatassa & dhammadesand & apariyadinnamyevassa \\
\hline & ce & apariyädinodyevassa & săriputta & tathăgatassa & dhammadesană & apariyâdiloparmyevassa \\
\hline & Ee & apariyadinnâyevassa & săriputta & tathägatassa & dhammadesana & apariyâdingamyevassa \\
\hline & Ko1 & apariyädipoảyeca & săriputta & tathăgatassa & dhammadesanã & apariyädippamyeva \\
\hline & $\mathrm{k} 02$ & apariyadinoāyeca & sâriputta & tathsgatassa & dhammadesana & apanyadinnamyeva \\
\hline & k03 & apariyàdinnayevassa & săriputta & tathăgatassa & dhammadesana & aparyadinnamyevassa \\
\hline \multirow[t]{6}{*}{ - Do Comparison } & $\Rightarrow$ & apariyàdinnä̀evassa & săriputta & tathathagagatassa & dhammadesana & apariyádinnamyevassa \\
\hline & Kos & apariyãdinnāyevassa & săriputta & tathăgatassa & dhammadesanā & apariyâdinnamyevassa \\
\hline & $\mathrm{kgs}$ & apariyadinoayeva & sariputta & tathagatassa & dhammadesana & aparyadinnamyeva \\
\hline & MO1 & apariyadinnayevassa & sariputta & tathaggatassa & dhammadesand & apariyädinnamyevassa \\
\hline & Se & apariyadinnäyevassa & sariputta & tathăgatassa & dhammadesana & apariyadinnamyevassa \\
\hline & 101 & apariyädinnäyevassa & săriputta & tathăgatassa & dhammadesana & apariyaddingeàyevassa \\
\hline
\end{tabular}

Figure 3 Sample of the synoptic table

creating a synoptic table with reference to the Burmese printed edition (Chattha sangāyana edition) as the preliminary text. Then, the content of all selected Khom script manuscripts and those from other traditions has been compared in the synoptic table word by word.

Based on the palm-leaf Manuscript found in Cambodia, the area of comparison will be focused on the Sīhanādavagga of the Mūlapaṇnāsa in the Majjhimanikāya texts beginning from the end of the Mahāsīhanādasutta to the end of the Anumānasutta. Its length is around 50 pages of palm-leaf manuscript or 4,670 words. As well as this, manuscripts from other tradition have been used. One set of Tham script and one set of Mon script manuscript from Thailand, five sets of Burmese script manuscripts from Myanmar and five sets of Sinhalese script manuscripts from Sri Lanka.

\section{Comparison Result of Selected Khom Script Manuscripts}

Even though the overview content of each manuscript is almost the same, many significant omissions and differences are found. For instance, at the end of the 


\begin{tabular}{|c|c|c|c|c|c|c|c|c|c|}
\hline K01 & $\wedge$ & $\hat{n}$ & $\wedge$ & $\hat{\Lambda}$ & $\hat{A}$ & $\hat{\Lambda}$ & $\wedge$ & $\wedge$ & $\wedge$ \\
\hline K02 & $\wedge$ & $\wedge$ & $\wedge$ & $\wedge$ & $\wedge$ & $\wedge$ & $\wedge$ & $\wedge$ & $\wedge$ \\
\hline K03 & mameve & taṃ & sammā & vadamāno & vadeyya & asammohadhammo & satto & loke & upapanno \\
\hline K04 & mameve & $\operatorname{tam}$ & sammā & vadamāno & vadeyya & asamohadhammo & satto & loke & upapanno \\
\hline K05 & mameve & tam & sammā & vadamāno & vadeyya & asammohadhammo & satto & loke & upapanno \\
\hline K95 & $\wedge$ & $\wedge$ & $\wedge$ & $\wedge$ & $\wedge$ & $\hat{\wedge}$ & $\wedge$ & $\wedge$ & $\wedge$ \\
\hline
\end{tabular}

Figure 4 Samples of omission pattern

\begin{tabular}{|l|l|l|l|l|l|l|}
\hline K01 & sukhassa & ca & pahānāya & dukkhassa & ca & pahānā \\
K02 & sukhassa & pa & pahānā & dukkhassa & ca & pahānā \\
K03 & dukkhassa & ca & pahānā & sukhassa & ca & pahānā \\
K04 & dukkhassa & ca & pahānā & sukhassa & ca & pahānā \\
K05 & dukkhassa & ca & pahānā & sukhassa & ca & pahānā \\
\hline K95 & sukhassa & ^ & pahānā & dukkhassa & ca & pahānā \\
\hline
\end{tabular}

\begin{tabular}{|c|c|c|c|c|}
\hline K01 & me puggalo & $\wedge$ & appiyo & amanāpo \\
\hline K02 & me puggalo & n & appiyo & amanāpo \\
\hline K03 & ^ puggalo & me & арpiyo & amanāpo \\
\hline K04 & me puggalo & me & appiyo & amanāpo \\
\hline K05 & puggalo & me & appiyo & amanāpo \\
\hline K95 & me puggalo & $\wedge$ & appiyo & amanāpo \\
\hline
\end{tabular}

Figure 5 Samples of word transpositions

\begin{tabular}{l|l|l|l|l|l|l|l|l|}
\hline K01 & ayam & $\wedge$ & puggalo & appiyo & amanāpo & ahaṃceva & kho panayam \\
K02 & ayaṃ & $\wedge$ & puggalo & appiyo & amapo & ahaṃceva & kho panaayam \\
\hline K03 & ayaṃ & me & puggalo & appiyo & amanāpo & ahañceva & kho panassaṃ \\
K04 & ayaṃ & me & puggalo & appiyo & amanāpo & ahañceva & kho panassaṃ \\
K05 & ayaṃ & me & puggalo & appiyo & amanāpo & ahañceva & kho panassaṃ \\
\hline K95 & ayam & $\wedge$ & puggalo & appiyo & amanāpo & ahaṃceva & kho panaayam \\
\hline
\end{tabular}

Figure 6 Samples of word differences

Mahāsīhanādasutta, several words in K01, K02 and K95 are omitted while all of them are available in K03, K04 and K05. Moreover, these kinds of omission pattern appear in other several places, in total more than 50 words.

And, in several cases, we found word transpositions and obvious differences between the group of K01, K02, K95 and the group of K03, K04, K05, in total more than 60 cases.

Based on the comparison result, these selected Khom Script Manuscripts can be divided into two groups: group A (K01, K02, K95) and group B (K03, K04, K05).

\subsection{Group A (Thonburi Lineage)}

K01 is the manuscript of the Thonburi period $(1779 \mathrm{CE})$ that is the oldest one among these selected Khom script manuscripts. K02 and K95 (manuscript from Cambodia) are very similar to each other but their ages are unknown. However, their content is almost entirely consistent with K01. Therefore, it seems that K01, K02 and K95 come from the same or very close lineage. It could be called Thonburi lineage. As well as this, it seems that some parts 


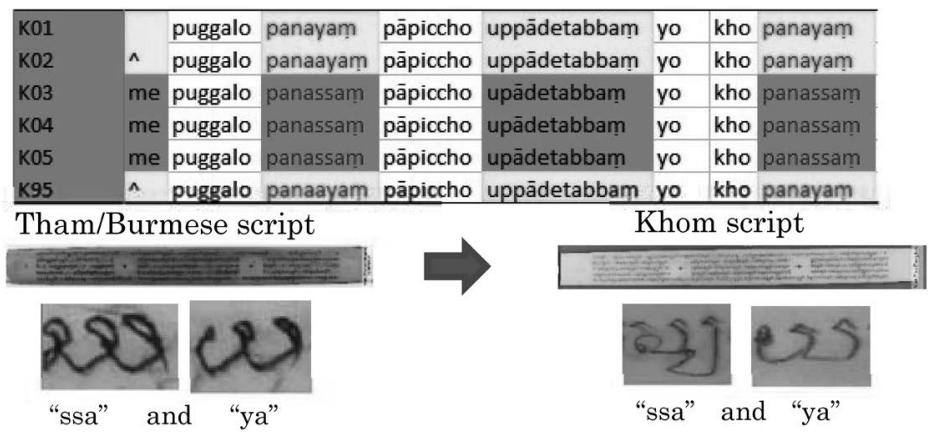

Figure 7 The confusion between "ssa" and "ya" in many places in K01, K02, and K95

of K01, K02, K95 agree with Burmese script manuscripts rather than Sinhalese script manuscripts. Additionally, many examples of transliteration confusion across traditions can be found, from "Tham/Burmese script" to "Khom script". For example, "ssa" and "ya" are in the set of similar letters in Tham/Burmese script not in Khom script, and the confusion between "ssa" and "ya" has been found in many places in K01, K02, and K95.

\subsection{Group B (Rattanakosin (Rama III) Lineage)}

K03, K04, K05 are the manuscripts of the Rattanakosin period in the reign of King Rama III (1824-1854 CE). Therefore, it could be called Rattanakosin (Rama III) lineage. Besides, it seems that some parts of K03, K04, K05 agree with Sinhalese script manuscripts rather than Burmese script manuscripts. Moreover, it feels that some parts of K03, K04, K05 agree with Thai printed edition, Syārattha edition (Se), rather than the group of the Thonburi Period (K01, K02, K95).

\subsection{Information of Pāli canon in Thonburi period}

Information about the Pāli Canon in Thailand and in Cambodia during the Thonburi period (1768-1782 CE) appears in historical documents. In the chapter "Legend of the Royal Pāli Canon” in The Legend of Library, Montein Dhamma library, Vajirañaña library, Buddhasangaha Library and the National Library states as follows:

In the last large war in Ayutthaya, the Burmese army did not attack Nakhon Si Thammaraja, therefore, a huge amount of Pāli Canon is surviving there. In the year 2312 BE (1769 CE), king Taksin with his army attacked Nakhon Si Thammaraja and borrowed the Pāli Canon from there back to Thonburi. He also asked senior monks to go to Cambodia and many cities to seek some 
texts of the Pāli Canon that cannot be found in Thonburi. ${ }^{2)}$

This information shows that there existed Khom script manuscripts in Cambodia at least since Thonburi period.

\section{Conclusion}

The comparison result demonstrates that the examined section of the Pāli Canon in Khom script manuscripts in Cambodia and Thailand come from the same lineage. Moreover, the Pāli Canon of Khom script manuscripts have been available in Cambodia at least since Thonburi period. It is also possible to state that Pāli Canon of Khom script manuscripts have been available in Cambodia since Ayutthaya period. Therefore, at that time, king Taksin would have known of the Pāli Canon in Cambodia. However, it is also worth noting that during the Ayutthaya period, some parts of recent Cambodia were still vassal states of Ayutthaya.

With regard to the question of whether Khom script manuscripts from Thailand and Cambodia belong to the same lineage and whether they have any significant differences, it seems that the differences are minimal and they both influenced each other.

As to the basic question of whether the Dhammachai Tipitaka Project needs make use of Khom script manuscripts from both countries for creating a database of palm-leaf manuscripts to produce a critical edition of the Pāli canon, based on the information studied, it is sufficient to focus exclusively on the Khom script manuscripts from Thailand.

\section{Notes}

1) See Srisetthaworakul (2018, 64-70).

2) Translated Srisetthaworakul from HRH Prince Damrong $(1916,4)$.

\section{Bibliography}

Srisetthaworakul, Suchada. 2018. "A Problem on the Origin of the Pāli Canon of Khom Script Manuscripts Found in Thailand and Cambodia." Indogaku bukkyogaku kenkyū 印度学仏教学研究 66(3): 6470. HRH Prince Damrong กรมพระยาดำรงราชานุภาพ. 1916. Tamnan Hor Phrasamud Hor Phra Motien Tham Hor Vajirayana Hor Buddhasangghaha lae Hor Phrasamud Samrub Phranakorn. ตำนานหอพระสมุด หอพระมณเทียรธรรม หอวชิรญาณ หอพุทธสาสนสังคหะ แลหอพระสมุดสำหรับพระนคร. Bangkok: Krom Silapakorn.

Key words Majjhimanikāya, Khom script, Palm leaf manuscript, Pāli canon, Siam, Khmer, Thailand, Cambodia, Comparison, Lineage

(DCI-Dhammachai Tipitaka Project Thailand \& PhD) 